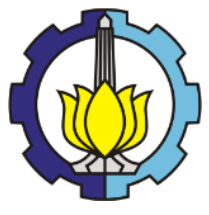

\author{
$8^{\text {th }}$ International Conference on \\ Architecture Research and Design (AR+DC) \\ November 1-2, 2016
}

ARtDC

\title{
Ethics after theory
}

\author{
CHAN Kok Hui, Jeffrey ${ }^{a^{*}}$ \\ ${ }^{a}$ Assistant Professor, Department of Architecture, School of Design and Environment, \\ National University of Singapore, 4 Architecture Drive, Singapore 117566, Singapore \\ *Corresponding author. Tel.: +65-6601-1643; fax: +65-6779-3078. \\ E-mail address: akickhj@nus.edu.sg
}

\begin{abstract}
Today, architectural theory has atrophied. Despite a perceived need for different theoretical ways of clarifying, explaining and understanding the complex phenomena of contemporary architectural production prior to a designer's intervention, there are few existing theoretical frameworks. Without either the descriptive or projective enablement by theory, conscientious and critical practices in architecture will have few alternatives against the tide of neoliberal city-making. In this paper, I make a pun of Speaks's (Speaks, 2006) paper titled, 'Intelligence after theory' by arguing that while (design) intelligence is necessary, it is however not sufficient. Ethics is also needed in architecture. Through a brief restatement of a canonical debate in the critical school of architectural theory, I argue why ethics is needed in architecture, and how ethics could be further developed through theory and theorization.
\end{abstract}

Keywords: ethics; contemporary architecture; architectural theory; design intelligence

\section{Introduction: the many 'uses' of theory and the crisis of place}

Despite a somewhat protracted history and despite that all schools of architecture have courses with the word 'theory' in them, the nature of theory and what 'architectural theory' means remain far from clear (Lang, 1987). According to the Beaux-Arts tradition, architectural theory was once limited to the set of rules and principles guiding the architect's design compositions (Lavin, 1990; Lucan, 2012). But since the nineteenth century and further spurred by the academization of architecture in the $20^{\text {th }}$ century (Speaks, 2006), definitions of 'architectural theory' have expanded. Today, architectural theory is taken to mean any kind of intellectual discourse outside the activity of design, which is at least likely to comprise of the histories of buildings (or theories), and criticism of these histories and theories (L. Martin, 2012). Conversely, every kind of ideas and concepts associated to architecture still seeking their place could also be categorized under 'architectural theory'. This openness of architectural theory promises intellectual democracy and conceptual vitality; but at the same time, there is also something apprehensive about a theoretical reality that is constantly amorphous - especially for an important field of knowledge and practice like architecture. It is therefore unsurprising to find even theorists themselves uneager to defend architectural theory (Speaks, 2005, 2006), or perhaps discovering theory to be quite 'dead' (Hight, 2009).

But has theory truly "fallen into desuetude" (Speaks, 2006)? Because theory is the intellectual terrain that underpins design practices (Taylor \& Levine, 2011), the real question is not whether theory has become 'disused' or even 'dead', but instead, what theories are useful or relevant for contemporary architecture today? Without theorydefined here as knowledge that can foreground units of analysis and explain hypotheses in architecture-it is not possible to abstract, contextualize, understand or even predict any built forms and their impacts on the human experience. Importantly, theory also permits one to understand architecture in relation to some larger intellectual 
framework and in this way, reaffirms architecture's position as the most intellectual of the visual arts (Lavin, 1990). And when this theory is systematic, architecture can exceed its status as a material craft and (service) profession, and attain the status of a discipline, which at any given moment represents "the most well-honed efforts of human beings to approach questions and concerns of importance in a systematic and reliable way" (Gardner, 2000). Significantly, a discipline also serves as a repository for puzzles and open questions that are yet solvable, or perhaps cannot be solved, within the expertise and lifetime of its most outstanding members. These puzzles and open questions then become the epistemological premises for educating the next generation, and form a continuous intellectual lineage connecting one generation of architects to the next.

Therefore, it is puzzling to discover a general "slackening" in the activity of theorizing today (Taylor \& Levine, 2011), when instead, more efforts should be devoted to clarifying the basis, structure and aims of different theories relevant and useful for architecture. Importantly, this slackening not only impacts theory development and transmission within the academia, but it also translates into a kind of helplessness, tantamount to haplessness, in practice. Specifically, I suggest that the crisis of place in architecture-defined as the absence of an effective counter-response, practical or theoretical, to the concerted and rapacious advances of neoliberal place-making institutions and developments today (Mayer, 2010) — could be seen as a direct casualty of this slackening.

Increasingly salient and rapidly accelerated, massive developmental projects have become a key staple of contemporary architectural production all over the world today, especially pronounced in fast-paced Asia. Entire city blocks (if not cities themselves) have been overturned to make way for large-scale urban projects that have unfortunately come to characterize most of Asian urbanism. It is like the Haussmannization of Paris all over again; only now, it is far more constant, intense, and incurs destruction on a larger — environmental and global—scale. To paraphrase the architectural critic Ada Louise Huxtable (Huxtable, 2001) here, 'development has become destiny', for much of contemporary architecture today.

And often masquerading as the materialization of authentic, endearing and impressionable spaces, many of these projects in contemporary architecture only turn out to become artificial places: the epitome of sterile 'placelessness', where 'place' when it exists, is merely harnessed as an image to sell more effectively (Relph, 1996) within the experience economy (Pine \& Gilmore, 2011). One such telling project is the recent case of Oculus, a shopping mall and transit hub designed by architect Santiago Calatrava on the Ground Zero site in Lower Manhattan, which has been criticized for being insensitive to the history, and the gravitas, of this place (Dunlap, 2016). Indeed, is the celebration of buying and selling by architecture even appropriate to the historical gravity of mass violence and the memories of the deceased in this place? Is the architect really a tool of whatever system he or she operates in (Goodman, 1971)? And has the architect ceased to question the design brief (Medina, 2015)? On this, architectural theory has largely fallen silent on the crisis of place even when theory presents the very source of help to clarify, explain and offer recourses. In the words of Martin (R. Martin, 2011) commenting on the Occupy Wall Street in New York City, "architectural thinking can contribute something invaluable...by offering tangible models of possible worlds, possible forms of shelter, and possible ways of living together, to be debated in general assemblies both real and virtual." On the other hand, silence implies that there is no better alternative-or other moral visions of space and place-beyond the flattened reality of such commerce-led developments. This onedimensional worldview of development then renders architectural theory ineffective, if not completely nullified: after all, what is the point of theorizing when there can be no expected better utility or possibility?

\subsection{Structure of the paper and the need for ethics}

In this paper, I argue for a reinstatement of architectural theory in a milieu when theory has ostensibly been sidelined. Furthermore, I contend that while certain subsets of architectural theory might have gone out of intellectual circulation for various reasons, however relevant theories and theorization in architecture have yet to relinquish their significance. If the discipline of architecture is said to comprise of autonomy (i.e., critique, representation and signification) and instrumentality (i.e., projection, performativity and pragmatics) (Somol \& Whitin, 2002), then it is possible to suggest that while the ideologies underpinning the project of autonomy might have wavered, the directive of instrumentality concerning the productive use of theories has hardly changed.

And on this note, I further suggest that theory has become even more essential in the contemporary context. Today, architects work across political and cultural boundaries (McNeill, 2009), confronting unprecedented realities 
and dilemmas that have to be first framed and understood theoretically before they can meaningfully and responsibly intervene through design. On the other hand, young architects (or aspiring students) interested in pursuing critical practice-defined as an organized and systematic activity that mobilizes architecture as a conceptual, creative and constructive possibility to question inequitable practices or to materialize positive and more equitable futures - have nowhere to turn to for intellectual inspiration. However, a growing and vibrant theoretical climate in architecture may present the necessary and formative environment for such inspirations to thrive.

Specifically, I shall then argue for the relevance of ethics in architectural theory. As an acknowledgment to Speaks's (Speaks, 2006) 'Intelligence after theory', I concur with Speaks that intelligence is necessary for architectural innovation, but it is however not sufficient. By intelligence, (Speaks, 2006) implies the need for innovative problem solving governed by an entrepreneurial logic: to discover new design opportunities in the market economy against what he perceives as the passivity (or fatalism) of Tafurian architectural theory against this market economy. Furthermore, he implies in an earlier piece of writing that this intelligence has to do with a form of nonideological, opportunistic and open learning in an uncertain (business) environment—adding value on top of solving the problem through design (Speaks, 2002). But I posit that his position on this form of value-added intelligence is inadequate. Instead, the real question for architecture has always been: how ethical is our creativity (or innovative intelligence) in design (Moran, 2014)? Because architecture is quintessentially about the activities of inhabitation and emplacement in the environment (Mugerauer \& Manzo, 2008), intelligence alone is insufficient; a concern for ethics is also paramount.

Furthermore, this emphasis on ethics is hardly founded on just its inherent appeal in architecture. Through the brief survey of a debate on the 'critical canon' of architectural theory, I suggest that ethics is a common but tacit thread in this debate; moreover, ethics may also provide answers to the doubts raised by the various theorists in this debate. My aim is not to capture either the theoretical nuances or the genealogical divergences that have come to characterize the contemporary discourse of 'criticality' in architecture (Baird, 2004). Instead, I render this debatewhile genealogically remote from the Asian context but nonetheless still relevant in keeping to its counter-stance against much of contemporary architecture in Asia and elsewhere-as the theoretical backdrop in order to foreground my arguments for ethics in architecture.

Specifically, I examine the historiography of this debate prompted by (Speaks, 2005) questioning the validity of the 'critical canon'. I trace the development of this debate through the writings of Manfredo Tafuri (1935-1994) via (Hays, 2010), (Speaks, 2005), (Hight, 2009), and then (Deamer, 2015), before concluding in the case of the most recent Venice Architecture Biennale, 'Reporting from the Front' (Schumacher, 2016) curated by Alejandro Aravena. By analyzing the trajectory of this debate, I suggest that one missing assumption — and theoretical concept - in all these different theoretical positions and stakes is ethics; that only by acknowledging and then explicating the nature of this ethics can the discipline of architecture once more reconcile itself to the possibility of relevant, critical theories.

\section{A brief survey on the present status of the critical canon within architectural theory}

The 'critical canon' is one of the more distinctive discourses that have suffused and sustained much of the intellectual debates and discussions within Anglophone (but primarily North America) architectural theory since the 1960s. One important debate within this canon took place slightly more than a decade ago, which subsequently developed into what is now known as the 'post-critical school' (Deamer, 2015). Long buttressed by ideas from Tafuri and other Frankfurt School thinkers, the critical canon comprises of an ensemble of various avant-gardist theories too ambivalent to be summarized or categorized under any one single banner. Even so, it is not inaccurate to suggest that it is unambiguously focused on restating and resisting the different rationalities capitalism has imposed on architecture and architectural production. But finding these rationalities un-resistible (or inescapable) under the conditions of late capitalism, this critical canon also sought to define an autonomous sphere of intellectual discourse for architecture through theorization and theory. 
In this debate, (Speaks, 2005) argued against the relevance of this critical canon in a world structured by the conditions of the market economy. For Speaks, architecture, if it is to be properly advanced, has to shed the twin insularities of its autonomy and resistance that have long characterized the architectural avant-garde. Subsequently, architecture is to develop in ways that can be better aligned to the expectations and opportunities of the market economy. Observing that opportunities abound in a milieu shaped by the innovative zest of entrepreneurialism (i.e., this was during the boom before the Financial Crisis in 2008), Speaks argued that this critical canon has become something of an impediment to a culture of innovation in architecture. In his view, architecture schools should instead engage in technological and entrepreneurial experimentations in order to produce design knowledge better aligned to the needs and anticipations of the marketplace.

Speaks's position should first be contextualized in the milieu of his practice. Since the late 1960s, the critical canon in architectural theory has been shaped by a body of 'negative vanguard theories', which are not only critical of the status quo (especially the status quo of capitalism), but also are characterized by a state of profound design passivity stemming from a resistance against the institutional advances of capitalism - that in sum, contradicts what Speaks believes architecture is all about. This passivity is largely due to Tafuri's 'double-bind' - perceivably also a moral dilemma - which (Hays, 2010) summed up aptly, and is also worthwhile to cite in full:

"To the extent that architecture can function in a capitalist society, it inevitably reproduces the structure of that society in its own immanent logics and forms. When architecture resists, capitalism withdraws it from service - take it offline... Tafuri asserts the intolerable but inescapable conditions of possibility for contemporary architecture: to collapse into the very system that condemns architecture to pure means-ends instrumentality, or to retreat into hypnotic solitude, recognizing that there is no longer a need for architecture at all.” (Hays, 2010: 3)

In other words for Tafuri, to participate in architecture is to further the very cause of capitalism, and its immanent logics and forms; but to resist capitalism via architecture implies (very likely) the nullification of itself, which is self-contradictory - therefore, a 'double-bind'. And so (Speaks, 2005) proposes to advance the interests of architecture by breaking this 'double-bind': to work with the opportunities for innovation offered by the market economy rather than resisting them (with theory or otherwise).

While the logic in this 'double-bind' appears watertight - that is, if one accepts Tafuri's pessimistic, dialectical assumptions - in reality things are looser. Indeed, empirically it is uncertain if functioning as a conscientious architect within a capitalist society always and inevitably reproduces the structure of its immanent (oppressive) logics and forms. Architects can also locate various opportunities to design for those who have been sidelined by present economic institutions. For instance, Csutoras and Liando's recent temporary Kineforum Misbar in Jakarta is one example where the architects enacted design for inclusivity and justice (Harvey, 2014). This point has long been the staple of a softer blend of Tafurian thought espoused-ironically_by Speaks's teacher Fredric Jameson (Baird, 2004; Jameson, 1985). And in a recent reassessment of the different critical positions in contemporary architecture, (Deamer, 2015) suggests three plausible options: (i) to continue resisting capitalism as the precondition and purpose of architecture by following the critical canon of Tafuri and Hays (and to remain confined to the rigidity of the 'double-bind'); (ii) to adopt Speaks's position, that is, the post-critical school, by aligning with the forces and opportunities of the market economy; or (iii) to identify the contradictions and gaps of capitalism and institutions of capitalism, and subsequently, by pursuing subversive projects or tactical reforms through architecture for a more equitable social state.

If Deamer is correct in showing the spread of these options, then contra Speaks, the critical canon in architectural theory has not so much lost its relevance; rather, it merely requires, and involves, a kind of practical savvy and conviction for spotting and adapting to the new conditions of late capitalism implied by the third option. In other words because this third option has never been closed off at any point in time, it is unclear if (Speaks, 2005) was simply tendentious in his interpretation of the critical canon and its perceived rigidities, or merely reacting out of his better interest to align with the opportunities of the market economy. 


\subsection{The missing—or avoided—assumption? Ethics in architectural theory}

However, neither Jameson nor Deamer explicitly mentioned the basis of the conviction in their respective version of theory. Is this conviction merely grounded in the ideology of class-conflict? Even if it is, is not this ideology also founded on deeper virtues - virtues such as greater equality or even compassion, which in one consistent form is the ethical belief that it is wrong to enjoy bountiful abundance while many others have next to nothing or suffer from poverty? In other words, the de-coupling of ideology from ethics reveals that while the Tafurian ideology has to presume ethics, however ethics does not need to presume Tafurian ideology. The history of architecture is replete with architects who did not explicitly subscribe to the Tafurian ideology (or Marxian ideologies for that matter), but who nonetheless either had periodically stepped away from commercial practice to help, or had devoted their professional lives toward addressing some deep social needs or injustices (e.g., Rural Studio, or Architecture for Humanity). These are also practices that appear morally consistent to what Jameson, Hays, or even Tafuri may espouse as a form of critical architecture (Baird, 2004). In other words through this decoupling, it is possible to relinquish the stranglehold of Tafuri's 'double-bind' yet adhere to its ethic - only if because an architect has a conscience and architectural production also has agency (Awan, Schneider, \& Till, 2011). Even so, this 'architectural conscience', or the ethics that can better specify this agency, has yet to be fully explicated by any systematic architectural theory.

Subsequently, it was (Hight, 2009) who picked up on the aftermath of this debate in an article pronouncing the 'death of theory'. Hight is certainly correct when he suggests that the debate of (Speaks, 2005) versus the critical canon was not only an internal (and generational) skirmish within the ranks of the critical canon in architectural theory, but also that it hardly represented the general — and growing-horizon of what architectural theory should come to entail. In Hight's view, pressing issues such as climate change, income inequality, sustainability, radical terrorism and securitization all can impact architecture, and these issues ought to rightly fall under the purview of any relevant architectural theory. To boost the discipline's chance in confronting these issues as each can come to impact practice, Hight suggests that it is necessary to engage these concerns theoretically in architecture. Yet again for Hight's call to be heeded, his argument has to assume the same kind of moral conviction or ethics. Indeed, why should an architect probe into issues and problems canonically considered external to the discipline unless she is also willing to take on new responsibilities that are considered supererogatory? And is not the willing acceptance of supererogatory responsibilities also an indicator of superior moral behavior? Therefore, Hight's attempt to contemporize Speaks's debate has merely resurfaced the need to acknowledge some kind of moral convictions in architecture - which Hight only presumed but was unready to answer.

Here, I suggest that Hight's call to widen the scope of architectural theory was addressed — but only in part-in the recent $15^{\text {th }}$ Venice Architecture Biennale 2016, titled, 'Reporting from the Front'. In stark contrast to all prior Biennales, this Biennale showcases the different and many social and political roles architecture play, and how these efforts are indicative of the broader relevance of architecture to the most urgent issues and problems in the world: issues such as migration, pollution, waste and human rights violations among many others (Wainwright, 2016). While the direction of the 2016 Biennale could be perceived as a rebuff to the relatively insular 2014 Biennale curated by Rem Koolhaas, it is also consistent to suggest that the 2016 Biennale is but a demonstration of how the discipline of architecture could begin to assume greater responsibilities in an increasingly uncertain and volatile world. However, this curatorial direction by architect Alejandro Aravena is not without detractors. Of note, Patrik Schumacher has publicly denounced Aravena's attempt as dabbling in issues external to the discipline of architecture, which ought to only concern itself with the "real" agendas of architecture (Schumacher, 2016) - even though he does not exactly say what these real agendas are. And despite that many exhibits showcased in the Biennale can be considered demonstrations of architecture's supererogatory responsibilities, one would be hardpressed to locate either the word 'ethics', or some descriptions consistent to 'moral responsibility' in any of the writings accompanying these exhibit (i.e., the author, who visited the Biennale during the Preview week to study it, could not find any instances even though he really tried). To quote a curator from a prominent museum during a personal conversation: "it was as if the word 'ethics' was deliberately, and systematically removed" (personal correspondence). Therefore yet again like (Hight, 2009), it is not possible to advance the discipline of architecture fruitfully unless architects begin to acknowledge and explicate the nature of their ethics: values and convictions that 
go beyond professional concerns, which are presumed by the type of engagements showcased in the Biennale. And without explicating this ethics, Schumacher's claim of suspicion that these architectural engagements were merely 'posturing' and playing to the tune of political correctness can never be properly countered.

\section{Ethics after theory}

Therefore, to follow through on the theoretical bottlenecks aforementioned, it is important to address both the reluctance and neglect of ethics in architecture. Empirically however, it is somewhat puzzling to observe this degree of reluctance to acknowledge ethics in architecture despite that a significant number of students in architecture entering the field are motivated to improve lives and the living environment. In one authoritative study conducted by the Carnegie Foundation for the Advancement of Teaching on architecture education (Boyer \& Mitgang, 1996), it was found that slightly less than half of all the students surveyed elected to study architecture not so much out of motivations for money or prestige, but because they wanted to improve the quality of life in their community and the built environment. If this finding is taken as an indication for a large group of architecture students in every generation, then there is all the more reason to advance ethics in architecture as a form of knowledge that can guide them.

In the past, students who exhibited such moral convictions could find some modicum of intellectual reassurances (or guidance) within the various 'negative vanguard theories' of the critical canon. In other words, the moral convictions of these students could continue to be nurtured through insights or ideas found in these theories. However because many of these 'negative vanguard theories' were in large part derived from the political experiences and philosophies of the 1960s, they have gradually either lost most of their luster or relevance for the generation today, who are weaned on a vastly different ideological staple of experience and ideas (Hays, 1998). Without the commensurate knowledge that can help to inform and guide these moral convictions already present in a great number of architecture students, these convictions risk either being snuffed out eventually by the complex pressures of practice, or even distorted by agendas inimical to the aims of architecture. Therefore, to maintain the relevance and significance of architectural theory and simultaneously to nurture these moral convictions, it is important to develop a theoretical line of inquiry on ethics in architecture.

\section{Conclusion: The hypothetical constitution of ethics after theory in architecture}

But ethics is also a nascent line of inquiry in architecture. In concluding this paper, by revisiting the small cluster of literature on this subject, I suggest three promising vectors to establish a theory of ethics in architecture. They are namely:

\subsection{Ethics represented or embodied by a built work of architecture (Chan, 2015)}

This first vector represents the earliest and most contentious, but perhaps also the most familiar line of thinking on ethics in architecture. Chiefly, this vector suggests that a built work of architecture not only can represent certain moral values, but it also can come to embody these values. For instance, A.W.N. Pugin (1812-1852) thought that the Gothic style (i.e., aesthetics) represented the virtue of truthfulness (Saint, 2005); but many late reformist jails in $18^{\text {th }}$ century England were embodied with spatial features aiming to attain desirable behaviors (Evans, 1982), which the Panopticon (prison) remains the most familiar to architects. Contemporary examples of such architecture that embody the 'moral values' of their designers, and subsequently are given form before being imposed to 'steer behavior' abound (Schrijver, 2015): ranging from the communitarian ethos of New Urbanism, to road sharing urban design, to the interior architecture of casinos (Schüll, 2012) and even to prison design (Sperry, 2014). A recent debate on the role of the architects in creating such architecture, where "the architecture is the control" (Sanchez \& Field, 2015) took place in the United States (Sperry, 2014).

Despite the mounting evidence of this vector, architects and theorists have been slow to accept it. This vector has traditionally been criticized as nothing short of an "ethical fallacy" (Scott, 1980), or more recently, as a form of "phony ethics" (Till, 2009), or more generally as "a form of mysticism" misrepresenting ethics in a built work of architecture, which presumably has no human agency, hence incapable of either an embodiment of ethics or moral 
responsibility (S. Fisher, 2000). I suggest that these criticisms are a tad hasty. Importantly, none of these critiques acknowledge the examples of 'manipulative' designs I cited earlier, where it has been possible to emplaced certain design features with the aim of modifying or compelling desired or desirable behaviors. Even if architects continue to demur on the more drastic idea of value embodiment, it is still hard to dismiss the corollary claim that whenever architects build, their designs will shape the way people live and thus will either reinforce some existing patterns, or come to resist these patterns (Harries, 2010). In this way according to (Harries, 2010), architects can never escape the responsibility in choosing, or staking, a certain position in steering how people will come to dwell in the space they have designed. Preferential embodiment of some values that the architect perceives as 'virtues' is therefore only one short step away after the making of this necessary choice.

\subsection{Ethics within the institutions or processes of architectural production}

On the other hand, the second vector firstly presumes the differentiation between the architect as a person, and the architect as a professional bound to his or her own organizational context. Secondly, this vector also presumes that this organizational context can impact the quality of moral deliberations and actions of this architect. Because one of the purposes of any effective organization is to control and predict the actions of its executives via a code of conduct (Barnard, 1968), and because psychologists have also discovered that moral behaviors are sensitive to circumstantial variations in the environment (Doris, 2003), how an architect then becomes subjectivized by the value influences of his or her organization or practice environment is therefore an important dimension of study if theorists are to advance knowledge of ethics in architecture.

And naturally, this vector can first be broached through the discourse of role ethics (Wolgast, 1992), where the professional, subjected to a certain set of codes and obligations imposed by his or her institutional role, may act in ways otherwise found impermissible by the standards of social norms (Applbaum, 1999), or conversely, may not act in ways otherwise found permissible by the standards of social norms. Should an architect receive 'gifts' from a contractor? As an integral part of fostering personal relationships, gifting and receiving gifts is permissible, if not always encouraged. But in the context of professional practice, this practice of gifting and receiving gifts then implicates issues of conflicts of interest, which can cloud professional judgment. And when an architect is caught between the clients' wishes - which her superiors in the firm abide by - and the conflicting needs of the community where her work would be built, how should this architect decide (T. Fisher, 2010)? Should the architect immediately respond to her better conscience? Or should she attempt to reopen negotiations with her superiors and clients?

Importantly for this vector, conventional interpretations of such ethical dilemmas have either portrayed the architect as the 'prima donna' (Blake, 1976), who would decide according to his or her inclination, or otherwise, portrayed the architect as one who is to singularly represent and serve the clients' interests. Clearly, neither interpretation accurately reflects the moral complexities found in contemporary practice characterized by conflicting value systems and pluralistic interests. Developing this vector further through theory may help architects to better think about their obligations to society and environment on the one hand, and on the other, on how to better clarify such dilemmas and to propose substantive recourse when they are not amenable to an immediate resolution. If truly there can be no ideal resolution, then at least it is possible through this vector to discover the specifications of an ethical compromise.

\subsection{Ethics of the architect as a person}

Finally, the third vector posits the centrality of the personhood of the architect in ethics. In moral philosophy, this is also the most classical way of understanding ethics as virtue ethics: neither through moral rules nor (desired) consequences but through understanding the various attributes of the human character that enable what is deemed as desirable and ethical behavior. To the extent that a great number of exemplars have gone against all odds to materialize their moral visions for the benefit of the many despite social or organizational constraints (Damon \& Colby, 2015), there are sound reasons to think that virtue ethics also offers a way to advance ethics in architecture. 
Importantly, this is a vector that ought to be strategically but also cautiously pursued in architecture education. To contextualize virtue ethics in architecture is first to ask: what are the different virtues necessary for the responsible practice of architecture and specifically, how can they be attained? Empirically, honesty in material usage and integrity in craftsmanship still espoused by a number of conscientious practitioners - either corresponding to their own principles they bring into practice or out of their obligations to the standards of professional practicehave consistently resulted in better buildings, lesser material wastage and longer building life-spans. And anecdotally observing students who have participated in service learning studios working with under-privileged communities, these students tend to show greater awareness and empathy to actual and real needs over the imagined ones during design.

Even so, this vector also raises many uneasy questions. For example, what is considered a desirable character trait or virtue, and to what extent should educators reinforce this in design learning? And is character or virtue cultivation even part of learning in any modern research university? While there are again sound reasons not to include virtue cultivation in design learning, it is also important to recognize that architecture school represents the final phase of the student's formal learning before practice; and to relinquish this opportunity for cultivating certain virtues important for conscientious and responsible practice is also to abandon the only hope that can advance ethics in architecture systematically and substantively through the personhoods of these future architects.

\section{References}

Applbaum, A. I. (1999). Ethics for Adversaries : the Morality of Roles in Public and Professional Life. New Jersey: Princeton University Press. Awan, N., Schneider, T., \& Till, J. (2011). Spatial agency : other ways of doing architecture. New York: Routledge.

Baird, G. (2004). "Criticality" and Its Discontents. Retrieved September 14, 2016, from http://www.harvarddesignmagazine.org/issues/21/criticality-and-its-discontents

Blake, P. (1976). The master builders : Le Corbusier, Mies van der Rohe, Frank Lloyd Wright. Norton.

Boyer, E. L., \& Mitgang, L. D. (1996). Building community : a new future for architecture education and practice : a special report. Carnegie Foundation for the Advancement of Teaching.

Chan, J. (2015). Moral Agency in Architecture? The Dialectics of Spatializing Morality and Moralizing Space. In Architecture, Materiality and Society (pp. 198-214). London: Palgrave Macmillan UK. https://doi.org/10.1057/9781137461131_10

Damon, W., \& Colby, A. (2015). The power of ideals : the real story of moral choice. New York: Oxford University Press.

Deamer, P. (2015). The architect as worker : immaterial labor, the creative class, and the politics of design. New York: Bloomsbury Academic.

Doris, J. M. (2003). Lack of character: personality and moral behavior. New York: Cambridge University Press. Retrieved from http://www.cambridge.org/id/academic/subjects/philosophy/logic/lack-character-personality-and-moralbehavior?format=PB\&isbn=9780521608909\#5uOVZFYKvoIIISeE.97

Dunlap, D. W. (2016). A Shopping Mall at Ground Zero, Uninformed by Its Sacred Land. Retrieved September 14, 2016, from https://www.nytimes.com/2016/09/06/nyregion/westfield-world-trade-center-mallocculus.html?action=click\&pgtype=Homepage \&version=Moth-Visible\&moduleDetail=inside-nyt-region-3\&module=inside-nytregion\&region=inside-nyt-region\&WT.nav=inside-nyt-region\&_r=1

Evans, R. (1982). The fabrication of virtue : English prison architecture, 1750-1840. Cambridge: Cambridge University Press.

Fisher, S. (2000). How to think about the ethics of architecture. In W. Fox (Ed.), Ethics and the built environment (pp. 170-182). London: Routledge.

Fisher, T. (2010). Ethics for architects : 50 dilemmas of professional practice. New York: Princeton Architectural Press.

Gardner, H. (2000). The disciplined mind: beyond facts and standardized tests, the K-12 education that every child deserves. New York: Penguin Books.

Goodman, R. (1971). After the planners. New York: Simon and Schuster.

Harries, K. (2010). The Responsibility of Design. In S. Bandyopadhyay, J. Lomholt, N. Temple, \& R. Tobe (Eds.), The Humanities in Architectural Design (pp. 7-15). Oxfordshire: Routledge.

Harvey, D. (2014). The Crisis of Planetary Urbanization | post. Retrieved September 14, 2016, from http://post.at.moma.org/content_items/520the-crisis-of-planetary-urbanization

Hays, K. M. (1998). Architecture theory since 1968. Cambridgeshire: The MIT Press.

Hays, K. M. (2010). Architecture's desire : reading the late avant-garde. Cambridge: MIT Press.

Hight, C. (2009). Meeting the New Boss: After the Death of Theory. Architectural Design, 79(1), 40-45. https://doi.org/10.1002/ad.808

Huxtable, A. L. (2001). The New York Process. Retrieved September 14, 2016, from https://www.wsj.com/articles/SB1000694510318778200

Jameson, F. (1985). Architecture and the critique of ideology. In J. Ockman (Ed.), Architecture, criticism, ideology (p. 191). Princeton, N.J. : Princeton Architectural Press.

Lang, J. T. (1987). Creating architectural theory: the role of the behavioral sciences in environmental design. New York: Van Nostrand Reinhold Co.

Lavin, S. (1990). The uses and abuses of theory. Progressive Architecture, 71(8), 113-114.

Lucan, J. (2012). Composition, non-composition: architecture and theory in the nineteenth and twentieth centuries. Lausanne, Switzerland : EPFL Press .

Martin, L. (2012). History, Theory, Criticism: The development of an intellectual discourse. In J. Ockman \& R. Williamson (Eds.), Architecture 
school: three centuries of educating architects in North America (p. 440). MIT Press.

Martin, R. (2011, November 7). Occupy: What Architecture Can Do. https://doi.org/10.22269/111107

Mayer, M. (2010). Social movements in the (post-) neoliberal city. (J. Fezer \& M. Gorlich, Eds.). London: Bedford Press.

McNeill, D. (2009). The Global Architect: Firms, Fame and Urban Form - Donald McNeill - Google Buku. New York: Routledge.

Medina, S. (2015). Affordability Won't Solve Housing Crisis. Public Housing Will. Retrieved September 14, 2016, from http://www.metropolismag.com/cities/housing/affordability-wont-solve-housing-crisis-public-housing-will/

Moran, S. (2014). Introduction: The Crossroads of Creativity and Ethics. In The Ethics of Creativity (pp. 1-22). London: Palgrave Macmillan UK. https://doi.org/10.1057/9781137333544_1

Mugerauer, R., \& Manzo, L. (2008). Environmental dilemmas : ethical decision making. Lanham: Lexington Books.

Pine, B. J., \& Gilmore, J. H. (2011). The Experience Economy, Updated Edition. Boston: Harvard Business Review Press.

Relph, E. (1996). Reflections on Place and Placelessness. Environmental \& Architectural Phenomenology, 7(3). Retrieved from https://sdvigpress.org/pub-114270

Saint, A. (2005). Practical wisdom for architects: The uses of ethics. In Architecture and its ethical dilemmas (pp. 7-11). London; Taylor \& Francis,

Sanchez, R., \& Field, A. (2015). What's life like in Supermax prison? - CNN.com. Retrieved August 14, 2016, from http://edition.cnn.com/2015/06/25/us/dzhokhar-tsarnaev-supermax-prison/

Schrijver, L. (2015). Design for Values in Architecture. In J. van den Hoven, P. E. Vermaas, \& I. van de Poel (Eds.), Handbook of ethics, values, and technological design: sources, theory, values and application domains (pp. 589-611). New York: Springer-Dordrecht.

Schüll, N. D. (2012). Addiction by design : machine gambling in Las Vegas. New Jersey: Princeton University Press.

Schumacher, P. (2016). Appraisal of the Venice Architecture Biennale 2016. Retrieved September 14, 2016, from http://www.patrikschumacher.com/Texts/Where is Architecture_Appraisal of the Venice Architecture Biennale 2016.html

Scott, G. (1980). The architecture of humanism. London: Architectural Press.

Somol, R., \& Whitin, S. (2002). Notes around the Doppler Effect and other moods of Modernism. Perspecta, 33, 72-77.

Speaks, M. (2002). Design Intelligence. Part 1: Introduction.

Speaks, M. (2005). After theory. Architectural Record, 72-75.

Speaks, M. (2006). Intelligence after Theory. Perspecta, 38, 101-106. https://doi.org/10.2307/40482421

Sperry, R. (2014). Architects and torture: What color is your waterboard? Retrieved September 14, 2016, from http://edition.cnn.com/2014/12/23/opinion/sperry-architects-torture/

Taylor, W. M., \& Levine, M. P. (2011). Prospects for an ethics of architecture. New York: Routledge.

Till, J. (2009). Architecture depends. New York: MIT Press.

Wainwright, O. (2016). Alejandro Aravena's Venice architecture biennale: "We can"t forget beauty in our battles'The Guardian. Retrieved September 14, 2016, from https://www.theguardian.com/artanddesign/2016/may/26/venice-architecture-biennale-alejandro-aravena

Wolgast, E. H. (1992). Ethics of an artificial person : lost responsibility in professions and organizations. Stanford University Press. 